\title{
Exploring the relationship between life expectancy at birth and economic growth in 56 developing countries
}

\author{
Metin Gürler', Özlem Özsoy² \\ 1 Uluslararası Rekabet Araştırmaları Kurumu (URAK), Istanbul, Turkey, ${ }^{2}$ Ekol Hospital, Izmir, Turkey \\ Keywords: economic growth, life expectancy, global health \\ https://doi.org/10.29392/joghr.3.e2019001
}

Journal of Global Health Reports

Vol. 3, 2019

\begin{abstract}
Background
Higher income per capita (IPC) means better access to public and private health services those are provided by public or private sectors in a country. Good health service which lowers mortality rates in a country promotes to reach a long living population level with a higher life expectancy at birth (LEB) and healthy labour force enhancing productivity. People feel themselves more productive with a good health care hence increasing productivity and working hours will cause an increase in IPC (economic growth) incessantly. In traditional economic growth theory, labour force which is one of the factors of production function has got an important effect on the country's economic growth. This study aims to investigate the relationship between LEB and IPC data and vice versa for 56 developing countries in North Africa, Middle-East and South-East Asia where most of them are Islamic countries and members of The Organisation of Islamic Cooperation (OIC).
\end{abstract}

\section{Methods}

Cross-section data analysis and panel data analysis consisting random and fixed effects estimations were used in the study to investigate the relationship.

\begin{abstract}
Results
According to the random and fixed effects estimation models with panel data analysis and cross-section data analysis in the study, LEB is found as one of the determinants of IPC and IPC as a main determinant of LEB in 56 developing countries. Granger causality test is also applied to test the direction of causality between LEB and national IPC for 56 developing countries and it is seen that IPC Granger causes LEB increase and vice versa for panel data. For cross-section data analysis there is no proved correlation between two variables.
\end{abstract}

\section{Conclusions}

In the manuscript 56 developing countries were analysed together. LEB and IPC promote each other not at once but in a time period. In the study our results show that economic growth Granger causes LEB increase and vice versa only for panel data not for cross-section data. The case or IPC not increasing to a higher level is called in literature as "Middle Income Trap". So benchmarking emerging countries is important to show the guidelines avoiding the "Middle Income Trap".

The improvements in healthcare system with the developments in innovation will decrease mortality rates in a country and promote to reach a long living population level with a higher LEB and healthy labour force enhancing productivity and economic growth in a country not in short term but in a time period. Economic growth not only increases income but also promotes technological investments in healthcare system as well.

Since the capital is a scarce input in developing countries labour force is the first and main determinant of the economic development especially in low- and middle-income countries. At the first stages of industrialization labour force is the key determinant of economic growth at the initial level of development for emerging countries. An improvement in health status of labour force increases the productivity resulting in an economic growth and enhancing IPC in a country.

The development of preventive and therapeutic methods against diseases will not only increase the citizens' LEB but the productivity of labour force in the country as well. Healthy labour force will cause increase in gross national income and IPC. IPC growth will also affect a healthy LEB 
positively. This positive feedback will last as the IPC increases continuously.

The relationship between LEB and IPC and vice versa of 56 developing countries was tested within the study empirically. A literature review of the subject summarizing some important previous studies theoretically and empirically was also conducted at the beginning of the study. The relationship between LEB on IPC was investigated by Cross Section and Panel Data Models using data gathered from the World Bank, Sesric (Organisation of Islamic Countries, Statistical, Economic and Social Research and Training Centre for Islamic Countries, UNDP (United Nations Development Programme) and IMF (International Monetary Fund).

In this study, totally 56 developing countries have been investigated by cross section and panel data analyses. The relationship between LEB and IPC for 56 developing countries has been tested with both Cross-sectional Data Method for the year 2015 and Panel Data Method for 26 periods starting from 1990 ending 2015. By giving priority to healthcare of the population productivity should be increased via getting a better health care and having long life and feeling well-being.

Granger causality test is also applied to test the direction of causality between LEB and IPC.

The Human Development Report which is regularly published annually by the United Nations, seems to have put people at the centre of the development. In the Human Development Indices and Indicators Report, ${ }^{1}$ countries were divided into four groups as the very high human development (59 countries according to the report), the high human development (53 countries according to the report), the medium human development (39 countries according to the report) and the low human development (38 countries according to the report). In the Human Development Report $2016^{2}$ the number of the countries which have got very high human development were 51 whereas it was 49 in the Human Development Report $2015 .{ }^{3}$ It seems there is an improvement in human development from 2015 to 2018. In the Human Development Reports, the countries are classified with the help of the human development index consisting of $3 \mathrm{sub}$-indices. The life expectancy sub-index that is defined as a dimension of long and healthy life where the LEB is an indicator of the sub-index. The education sub-index which tells knowledge dimension is another sub-index defined as a combination of mean years of schooling and expected years of schooling indicators. Gross National Income (GNI) in purchasing power parity which simply means decent standard of living is forming the third sub-index.

Table 1 consists of the basic studies investigating and analysing the relationship between LEB and IPC. It is generated by the authors.

\section{METHODS}

\section{ANALYSIS OF THE RELATIONSHIP BETWEEN LEB AND} IPC

\section{COUNTRY AND DATA SELECTION}

In the study panel data observation with the random and fixed effects models with 26 time periods between 1990 and 2015 and cross section data observation for the year 2015 of 56 developing countries were applied. The 56 developing countries are members of the OIC. The LEB data was collected from the World Bank and UNDP whereas IPC from the World Bank, Sesric and IMF.

An improvement in health status of citizens increases economic growth rate resulting with a boost in IPC and enhancing productivity in a country. Higher IPC means better access to health services those are provided by public or private sectors. Good health service which lowers mortality rates promote a country to reach a long living population with a higher LEB and healthy labour force.

Following the existing literature on the relationship between IPC and LEB, the estimated models in the study can be described as follows:

$\ln \left(\mathbf{Y}_{\mathbf{i t}}\right)=f\left(\mathbf{X}_{\mathbf{i t}}\right)$, ln: natural logarithm, $\mathbf{Y}_{\mathbf{i t}}:$ IPC, $\mathbf{X}_{\mathbf{i t}}:$ LEB

$\ln \left(\mathbf{Y}_{\mathbf{i t}}\right)=f\left(\mathbf{X}_{\mathbf{i t}}\right)$, ln: natural logarithm, $\mathbf{Y}_{\mathbf{i t}}:$ LEB, $\mathbf{X}_{\mathbf{i t}}:$ IPC

$\ln \left(Y_{i t}\right)=\boldsymbol{\alpha}+\boldsymbol{\beta} \times X_{i t}+\mathbf{v}_{\mathbf{t}}, \mathrm{i}=1,2,3 \ldots 56$ (countries), $\mathrm{t}=2015$ for cross-section data, $\mathbf{Y}_{\mathbf{i t}}$ : IPC or LEB, $\mathbf{X}_{\mathbf{i t}}$ : LEB or IPC

$\ln \left(Y_{i t}\right)=\boldsymbol{\alpha}+\boldsymbol{\beta} \times \mathbf{X}_{\mathbf{i t}}+\mathbf{v}_{t}, \mathrm{i}=1,2,3 \ldots 56$ (countries), $t=$ 1990-2015 (26 periods) for panel data, $\mathbf{Y}_{\mathbf{i t}}$ : IPC or LEB, $\mathbf{X}_{\mathbf{i t}}$ : LEB or IPC

IPC as an indicator of economic growth and LEB as an indicator of long and healthy life were used in the study. For the variables, natural logarithms of the values are used.

For panel data analysis 26 periods starting from 1990 and ending 2015 and for cross-section data analysis 2015 year were studied for 56 developing countries. $\boldsymbol{\alpha}$ is the constant coefficient (intercept) and $\boldsymbol{\beta}$ is the regression coefficient (independent variable coefficient/ slope). $\mathbf{v}_{\mathbf{t}}$ is the disturbance (error) term that represents the changes in IPC or LEB (increase / decrease) is not defined by LEB or IPC at time $\boldsymbol{t}$. $\mathbf{v}_{\mathbf{t}}$ is a random variable with well-defined probability properties and is $\mathbf{v}_{\mathbf{t}} \sim$ Normally and Independently Distributed (NID) $\left(\mathbf{0}, \boldsymbol{\sigma}^{\mathbf{2}}\right)$ where $\mathbf{v}_{\mathbf{t}}$ has zero $(\mathbf{0})$ mean and common variance $\left(\boldsymbol{\sigma}^{2}\right)$ for all countries according to the Classical Normal Linear Regression and is normally and independently distributed according to time and countries. ${ }^{14}$

\section{RESULTS}

\section{THE DEVELOPMENT OF IPC DURING THE PERIOD} $1990-2015$

Considering the development of IPC during the period 1995-2015 in the study, Qatar is the country which has got the highest IPC among 56 developing countries in 2015 (Figure 1). United Arab Emirates, Brunei Darussalam, Kuwait and Bahrain are the followers of Qatar in this indicator. Guinea, Mozambique, Gambia, Niger and Somalia are the countries who have lowest IPC. With a nearly US\$ 9.126 IPC which is more than 56 developing countries average amount of US\$ 6.871 but less than world average amount of 
Table 1. Selected studies analysing the relationship between LEB and economic growth

\begin{tabular}{|c|c|c|c|c|c|c|}
\hline Authors & Name of the study: & $\begin{array}{l}\text { Year of } \\
\text { the study: }\end{array}$ & $\begin{array}{l}\text { Countries observed } \\
\text { in the study: }\end{array}$ & $\begin{array}{l}\text { The study's } \\
\text { time period: }\end{array}$ & Method: & $\begin{array}{l}\text { Empirical } \\
\text { results: }\end{array}$ \\
\hline $\begin{array}{l}\text { Azomahou, } \\
\text { T.T., R. } \\
\text { Boucekkine } \\
\text { and B. } \\
\text { Diene }\end{array}$ & $\begin{array}{l}\text { A closer look at the relationship between life } \\
\text { expectancy and economic growth }\end{array}$ & 2009 & $\begin{array}{l}\text { Australia, Austria, Belgium, Canada, Denmark, } \\
\text { Finland, France, Italy, Japan, Netherlands, New } \\
\text { Zealand, Norway, Portugal, Spain, Sweden, } \\
\text { Switzerland, United Kingdom, USA. }\end{array}$ & $1820-2005$ & $\begin{array}{l}\text { GAM for } \\
\text { panel data }\end{array}$ & Positive \\
\hline $\begin{array}{l}\text { Acemoğlu, } \\
\text { D. and S. } \\
\text { Johnson }\end{array}$ & $\begin{array}{l}\text { Disease and Development: The Effect of Life, } \\
\text { Expectancy on Economic Growth }\end{array}$ & 2007 & 75 countries & $1940,1980,2000$ & OLS & $\begin{array}{l}\text { No } \\
\text { relationship. }\end{array}$ \\
\hline $\begin{array}{l}\text { Akintunde, } \\
\text { T.S., B.F. } \\
\text { Satope and } \\
\text { B.E. } \\
\text { Akanbi }^{6}\end{array}$ & $\begin{array}{l}\text { The Impact of Life Expectancy on Economic Growth } \\
\text { in Nigeria }\end{array}$ & 2016 & Nigeria & $1980-2012$ & VAR & Positive \\
\hline $\begin{array}{l}\text { Mahyar, } \\
\mathrm{H}^{7}\end{array}$ & $\begin{array}{l}\text { Economic Growth and Life Expectancy: The Case of } \\
\text { Iran }\end{array}$ & 2016 & Iran & $1966-2013$ & VAR & Positive \\
\hline $\begin{array}{l}\text { Ngangue, } \\
\text { N. and K. } \\
\text { Manfred }^{8}\end{array}$ & $\begin{array}{l}\text { The Impact of Life Expectancy on Economic Growth } \\
\text { in Developing Countries }\end{array}$ & 2015 & 141 Developing Countries & $2000-2013$ & $\begin{array}{l}\text { Dynamic } \\
\text { Panel Data }\end{array}$ & Positive \\
\hline Bowser, D. ${ }^{9}$ & $\begin{array}{l}\text { The Effect of Life Expectancy on Economic Growth } \\
\text { in U.S. }\end{array}$ & 2010 & United States & $1970-2000$ & $\begin{array}{l}\text { OLS and } \\
2 S L S\end{array}$ & $\begin{array}{l}\text { No } \\
\text { relationship. }\end{array}$ \\
\hline $\begin{array}{l}\text { Husain, } \\
\text { M.J. }{ }^{10}\end{array}$ & $\begin{array}{l}\text { Alternative Estimates of the Effect of the Increase } \\
\text { of Life, Expectancy on Economic Growth }\end{array}$ & 2012 & 59 countries & $1980-2004$ & $2 S L S$ & Positive \\
\hline Ecevit, E. ${ }^{11}$ & $\begin{array}{l}\text { The Impact of Life Expectancy on Economic } \\
\text { Growth: Panel Cointegration and Causality } \\
\text { Analyses for Organisation for Economic Co- } \\
\text { operation and Development (OECD) Countries }\end{array}$ & 2013 & 21 OECD Countries & $1970-2010$ & $\begin{array}{l}\text { Panel Co- } \\
\text { integration } \\
\text { and } \\
\text { Causality } \\
\text { Tests }\end{array}$ & Positive \\
\hline $\begin{array}{l}\text { Cervellati, } \\
\text { M. and U. } \\
\text { Sunde. }{ }^{12}\end{array}$ & $\begin{array}{l}\text { Life Expectancy on Economic Growth: The Role of } \\
\text { the Demographic Transition }\end{array}$ & 2009 & 47 countries & $1940,1980,2000$ & $\begin{array}{l}\text { OLS and } \\
2 S L S\end{array}$ & $\begin{array}{l}\text { Positive(after } \\
\text { demographic } \\
\text { transition) }\end{array}$ \\
\hline $\begin{array}{l}\text { Erdogan, } \mathrm{S} \text {. } \\
\text { and H. } \\
\text { Bozkurt } 13\end{array}$ & $\begin{array}{l}\text { The Relation Between Life Expectation and } \\
\text { Economic Growth in Turkey: An analysis with ARDL } \\
\text { Model }\end{array}$ & 2008 & Turkey & $1980-2005$ & ARDL & Positive \\
\hline
\end{tabular}

LEB - life expectancy at birth, , GAM - generalized additive model, OLS - ordinary least squares, VAR - vector autoregression, 2SLS - two-stage least squares, ARLD - autoregressive distributed lag 


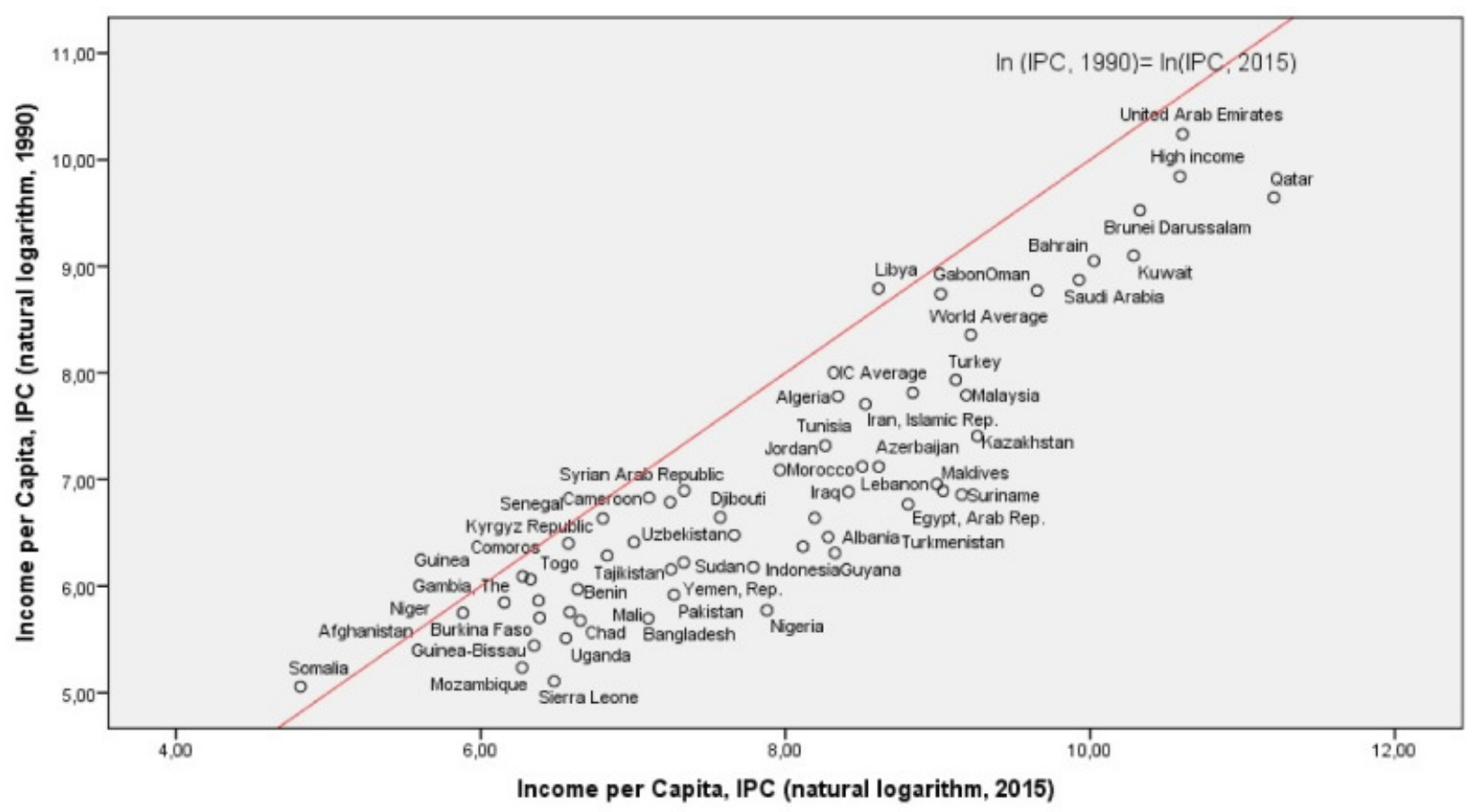

Figure 1. The development of IPC (1990-2015). ${ }^{15-17}$

US\$ 10.058, Turkey is ranked as $11^{\text {th }}$ country with high IPC in 2015. In the figure the upward line tells that IPC doesn't change from 1990 to 2015 and the countries below the line mean that the countries has got a progress in IPC where the countries upper the line mean a recession in IPC. It seems Suriname has got the best performance in increasing the IPC during the period 1990-2015 where Somalia has got the worst performance with a decrease in IPC.

\section{THE DEVELOPMENT OF LEB DURING THE PERIOD $1990-2015$}

For the period 1990-2015 only Cote d'Ivoire and Syria have a negative change rate in LEB among 56 developing countries. It can be obviously said that Turkey has ranked $13^{\text {th }}$ best performance in this indicator. Niger has got a nearly $40.8 \%$ of change rate for the period 1990-2015 ranking top where Turkey has got a $17.5 \%$ change rate in LEB. For the same period, Côte d'Ivoire has been the lowest change rate in LEB with a $1.3 \%$ decreasing rate. The world average is 9.5\% growth and 56 developing countries' average is $11.4 \%$ in the same period. Turkey has got a tremendous increasing LEB performance after 1990 (Table 2).

In the Figure 2 below considering LEB development during the period 1990-2015, Lebanon has got the highest LEB among 56 developing countries in 2015. Brunei Darussalam, Qatar, Albania and United Arab Emirates are the followers of Lebanon in this indicator. Cot' d'Ivoire and Sierra Leone are the countries who have lowest LEB among 56 developing countries where Turkey has ranked as $10^{\text {th }}$ country with 75.2 years LEB. In the figure the upward line tells that LEB doesn't change from 1990 to 2015 and the countries below the line mean that the countries has got a progress in LEB where the countries upper the line mean a recession in LEB.
It seems Niger has got the best performance in increasing the LEB during the period 1990-2015 where Cote d'Ivoire has got the worst performance with a lower increase in LEB performance.

\section{THE RELATIONSHIP BETWEEN LEB AND IPC WITH CROSS-SECTION DATA METHOD FOR 2015}

The Figure 3 which was estimated by SPSS software (IBM, Armonk, NY, USA) below shows the relationship between natural logarithm values of LEB and IPC for the year 2015. The positive relationship can be seen obviously between two variables with the line equation. The countries on the equation line indicates the countries where the natural logarithm values of LEB and IPC are equal. The equation tells us one unit increase in natural logarithm of IPC causes approximately $6.25 \%$ increase in natural logarithm of LEB which means nearly 4.09 years increase in LEB in 56 OIC's average.

In 2015, Lebanon is the leader country where Brunei Darussalam and Qatar are the following countries in LEB where Qatar is the leader in the IPC, United Arab Emirates as the second and Brunei Darussalam is the third country where Somalia seems as the country which has the lowest IPC in 56 developing countries.

If the relationship between natural logarithm values of LEB and IPC in Figure 3 is wanted to be expressed as a regression for 56 developing countries, the following equation is obtained. The relationship between the natural logarithm values of LEB and IPC is estimated with the cross-section data by the EViews 9 software (QMS, Emeryville, California, United States) (Table 3). The equation tells us that one year increase in natural logarithm value of IPC causes approximately $7 \%$ increase in natural logarithm value of LEB which 
Table 2. Comparison of LEB (56 developing countries, 1990-2015) 15,18

\begin{tabular}{|c|c|c|c|c|c|c|c|c|}
\hline \multicolumn{9}{|c|}{ LEB } \\
\hline Rank & Country Name & 1990 & 1995 & 2000 & 2005 & 2010 & 2015 & $\begin{array}{l}1990-2015 \\
\text { Growth }\end{array}$ \\
\hline 1 & Lebanon & 70.2 & 72.1 & 74.4 & 76.4 & 78.5 & 79.5 & $13.2 \%$ \\
\hline 2 & Brunei Darussalam & 73.1 & 74.2 & 75.3 & 76.0 & 77.6 & 79.0 & $8.1 \%$ \\
\hline 3 & Qatar & 75.1 & 75.9 & 76.5 & 76.9 & 77.8 & 78.3 & $4.2 \%$ \\
\hline 4 & Albania & 72.0 & 72.2 & 74.3 & 75.8 & 77.0 & 78.0 & $8.4 \%$ \\
\hline 5 & United Arab Emirates & 71.7 & 73.1 & 74.5 & 75.5 & 76.7 & 77.1 & $7.5 \%$ \\
\hline 10 & Turkey & 64.3 & 67.0 & 70.0 & 72.4 & 74.1 & 75.5 & $17.5 \%$ \\
\hline 52 & Mozambique & 43.1 & 45.9 & 48.7 & 50.6 & 53.2 & 55.5 & $28.7 \%$ \\
\hline 53 & Nigeria & 46.1 & 46.1 & 46.6 & 48.7 & 51.3 & 53.1 & $15.2 \%$ \\
\hline 54 & Chad & 46.9 & 47.4 & 47.6 & 48.0 & 49.9 & 51.9 & $10.6 \%$ \\
\hline 55 & Cote d'Ivoire & 52.6 & 49.6 & 46.7 & 47.8 & 50.2 & 51.9 & $-1.3 \%$ \\
\hline 56 & Sierra Leone & 37.4 & 35.7 & 38.7 & 43.6 & 48.2 & 51.3 & $37.3 \%$ \\
\hline \multicolumn{2}{|c|}{$\begin{array}{l}\text { Organization of Islamic Countries (OIC) } \\
\text { Average }\end{array}$} & 60.3 & 61.2 & 62.5 & 64.0 & 65.7 & 67.1 & $11.4 \%$ \\
\hline \multicolumn{2}{|c|}{ The World Average } & 65.4 & 66.3 & 67.6 & 69.0 & 70.5 & 71.6 & $9.5 \%$ \\
\hline
\end{tabular}

LEB - life expectancy at birth

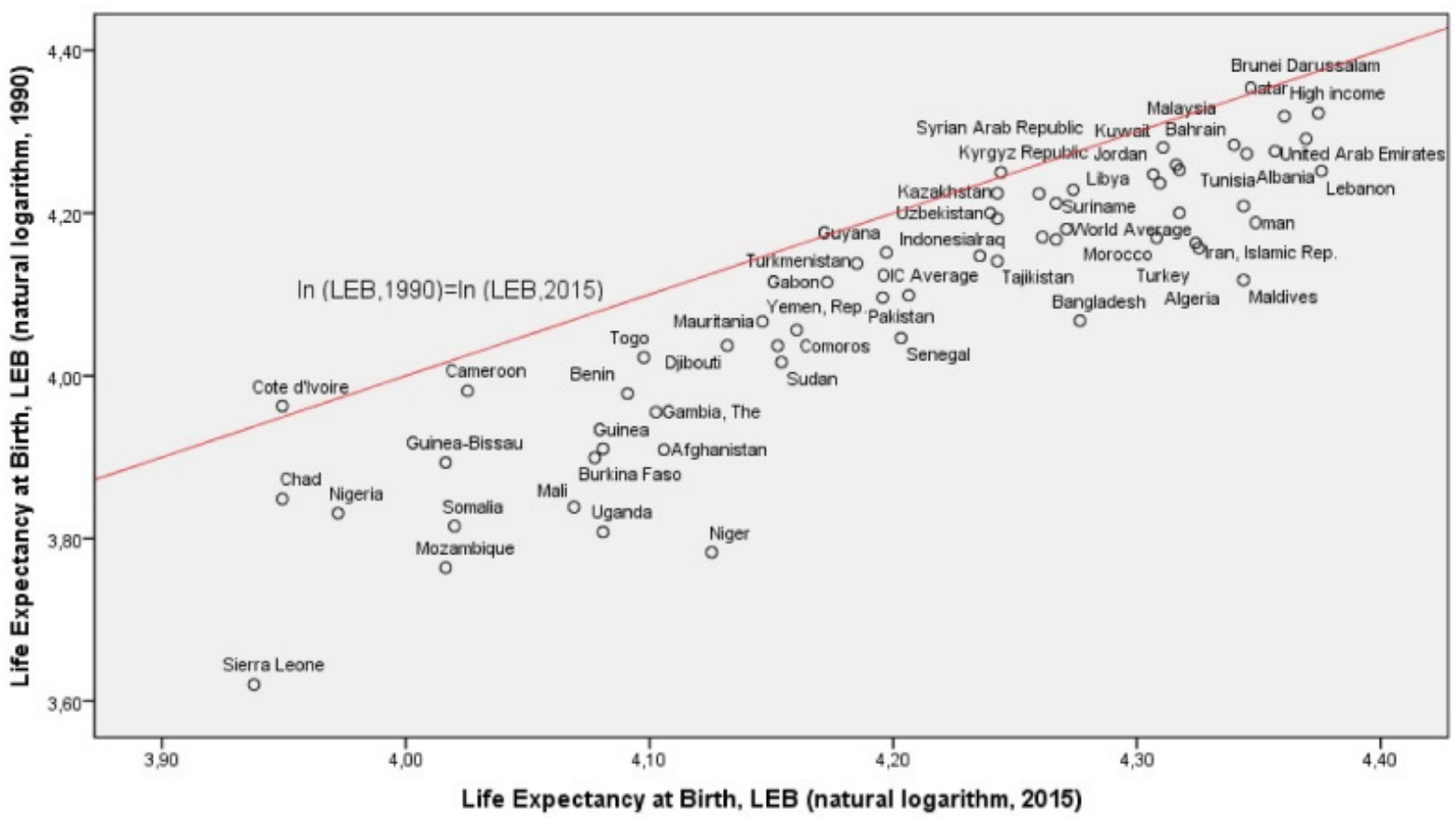

Figure 2. The development of LEB (1990-2015). ${ }^{15,18}$

means nearly US\$ 8.108 increase in IPC for 56 developing countries in average causes 4.51 years increase in LEB in 56 OIC's average.

$\ln (\mathrm{LEB})_{2015}=3.66+0.07 \times \ln (\mathrm{IPC})_{2015} \ln$ : natural logarithm Nearly $57.8 \%$ of the changes in LEB are expressed by IPC in the equation. The statistical values of the coefficients of the regression are statistically significant $(P<0.05$ and the absolute values of the coefficients $t$ are outside the threshold values of the $t$ distribution).
THE RELATIONSHIP BETWEEN LEB AND IPC WITH RANDOM EFFECTS MODEL (REM, 1990-2015)

The following estimated equation tells the relationship between the natural logarithm values of LEB and IPC by REM regression with panel data.

$$
\ln (\mathrm{LEB})_{1995-2015}=3.77+0.05 \times \ln (\mathrm{IPC})_{1995-2015}
$$

One unit increase in IPC causes an increase of nearly 0.05 units in LEB of the 56 developing countries. It means that nearly 8.108 USD increase in IPC for 56 developing coun- 


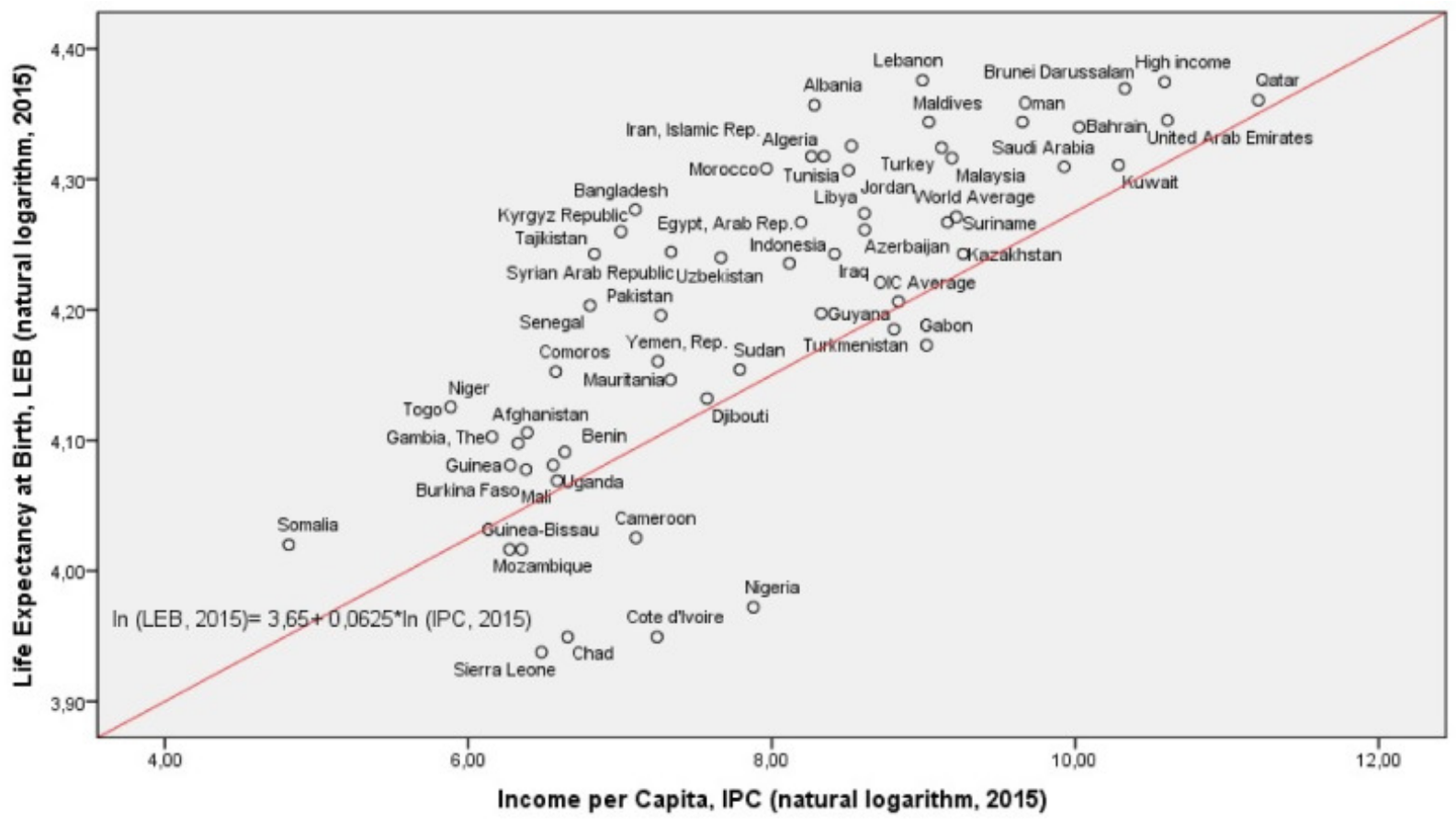

Figure 3. LEB and IPC relationship in 56 developing countries (2015). ${ }^{15-18}$

Table 3. The relationship between LEB and IPC with Cross-section Data Method (2015)

\begin{tabular}{|c|c|c|c|c|}
\hline \multicolumn{5}{|c|}{$\begin{array}{l}\text { Dependent Variable: LN_LEB } \\
\text { Method: Least Squares } \\
\text { Date: } 05 / 01 / 17 \text {, Time: } 17: 59 \\
\text { Sample: } 156 \\
\text { Included observations: } 56\end{array}$} \\
\hline Variable & Coefficient & Std. Error & T-Statistic & Prob. \\
\hline C & 3.657885 & 0.063899 & 57.24452 & 0.0000 \\
\hline LN_IPC & 0.068665 & 0.007991 & 8.593050 & 0.0000 \\
\hline R-squared & 0.577599 & Mean dependent var & & 4.198959 \\
\hline Adjusted R-squared & 0.569776 & S.D. dependent var & & 0.124115 \\
\hline S.E. of regression & 0.081409 & Akaike info criterion & & -2.143599 \\
\hline Sum squared resid & 0.357882 & Schwarz criterion & & -2.071265 \\
\hline Log likelihood & 62.02078 & Hannan-Quinn criter. & & -2.115556 \\
\hline F-statistic & 73.84050 & Durbin-Watson stat & & 2.078958 \\
\hline Prob(F-statistic) & 0.000000 & & & \\
\hline
\end{tabular}

C - constant, LN_IPC - natural logarithm of IPC; LN_LEB - natural logarithm of LEB, LEB - life expectancy at birth, IPC - economic growth, S.E. - standarderror, S.D. - standard deviation, R-squared - statistical measure that representsthe proportion of the variance for a dependent variable that's explained by an independent variable, F-statistic - the test statistic for testing the statistical significance of the model

tries in average causes nearly 3.27 years increase in LEB in average. If the regression is wanted to be obtained by pooled ordinary least squares method it would be as; ln $(\mathrm{LEB})_{1995-2015}=3.55+0.08 \times \ln (\text { IPC })_{1995-2015}$.

The relationship between the natural logarithm values of LEB and IPC in a REM regression with the panel data for the 56 developing countries by the EViews 9 software can be seen as below (Table 4).

The regression above shows that about $29 \%$ of the changes in the LEB is expressed by the IPC values of the 56 developing countries. When the statistical values of the coefficients of the regression are examined; IPC coefficient (slope) and the constant coefficient are statistically significant $(P<0.05$ and the absolute values of the coefficients' $t$ are outside the threshold values of the $t$ distribution). Considering the relationship between the LEB and the IPC values of the 56 developing countries according to the regression results obtained in previous section by using the Cross-sectional Data Method is also confirmed by the regression results obtained using the Panel Data Method. 
Table 4. The relationship between LEB and IPC with REM (1990-2015)

\begin{tabular}{|c|c|c|c|c|}
\hline \multicolumn{5}{|c|}{ Dependent Variable: LN_LEB } \\
\hline \multicolumn{5}{|c|}{ Method: Panel EGLS (Cross-section random effects) } \\
\hline \multicolumn{5}{|c|}{ Date: 05/01/17 Time: 19:07 } \\
\hline \multicolumn{5}{|l|}{ Sample: 19902015} \\
\hline \multicolumn{5}{|l|}{ Periods included: 26} \\
\hline \multicolumn{5}{|c|}{ Cross-sections included: 56} \\
\hline \multicolumn{5}{|c|}{ Total panel (balanced) observations: 1456} \\
\hline \multicolumn{5}{|c|}{ Swamy and Arora estimator of component variances } \\
\hline Variable & Coefficient & Std. Error & t-Statistic & Prob. \\
\hline C & 3.768913 & 0.019567 & 192.6153 & 0.0000 \\
\hline LN_IPC & 0.050412 & 0.002060 & 24.46688 & 0.0000 \\
\hline \multicolumn{5}{|c|}{ Effects Specification } \\
\hline \multirow{3}{*}{\multicolumn{2}{|c|}{$\begin{array}{l}\text { Cross-section random } \\
\text { Idiosyncratic random }\end{array}$}} & & S.D. & Rho \\
\hline & & & 0.093839 & 0.8154 \\
\hline & & & 0.044652 & 0.1846 \\
\hline \multicolumn{5}{|c|}{ Weighted Statistics } \\
\hline R-squared & 0.289621 & \multicolumn{2}{|c|}{ Mean dependent var } & 0.384235 \\
\hline Adjusted R-squared & 0.289132 & \multicolumn{2}{|c|}{ S.D. dependent var } & 0.053220 \\
\hline S.E. of regression & 0.044872 & \multicolumn{2}{|c|}{ Sum squared resid } & 2.927559 \\
\hline F-statistic & 592.7945 & \multicolumn{2}{|c|}{ Durbin-Watson stat } & 0.429430 \\
\hline Prob(F-statistic) & 0.000000 & & & \\
\hline \multicolumn{5}{|c|}{ Unweighted Statistics } \\
\hline R-squared & 0.479554 & Mear & t var & 4.135306 \\
\hline Sum squared resid & 18.62735 & Durk & stat & 0.067491 \\
\hline
\end{tabular}

C - constant, EGLS - Estimated Generalized Least Squares, LN_IPC - natural logarithm of IPC, LN_LEB - natural logarithm of LEB, LEB - life expectancy at birth, IPC - economic growth, S.E. - standard error, S.D. - standard

deviation, R-squared - statistical measure that represents the proportion of the variance for a dependent variable that's explained by an independent variable, F-statistic - the test statistic for testing the statistical significance of the model

To test the validity of the REM which shows the relationship between LEB and IPC obtained with the EViews 9 software above with the Hausman Test:

$\mathrm{H}_{0}$ : REM can be applied

$\mathrm{H}_{1}$ : Fixed Effects Model (FEM) can be applied.

The following Hausman test (Table 5) also shows that null hypothesis indicating REM can be applied may be rejected, since with $1 \mathrm{df}$ (degree of freedom) and $X^{2}$ (chisquare) value is statistically significant.

Since the null hypothesis is rejected, the alternative one which tells us FEM can be applied for the relationship should be accepted. The regression estimated by FEM should be as below.

$\ln (\text { LEB })_{1995-2015}=3.78+0.0486 \times \ln (\text { IPC })_{1995-2015}$

It means that nearly 8.108 USD increase in IPC for 56 developing countries in average causes nearly 3.16 years increase in LEB in average. The regression above shows that about $92.2 \%$ of the changes in the LEB is expressed by the IPC values of the 56 developing countries.

\section{THE RELATIONSHIP BETWEEN IPC AND LEB WITH CROSS-SECTION DATA METHOD FOR 2015}

The Figure 4 which was estimated by SPSS software (IBM, Armonk, New York, United States) below shows the rela- tionship between natural logarithm values of IPC and LEB for the year 2015. The positive relationship can be seen obviously between two variables with the line equation. The countries on the equation line indicates the countries where the natural logarithm values of IPC and LEB are equal.

If the relationship between the natural logarithm values of IPC and LEB in Figure 4 is wanted to be expressed as a regression, the following equation is obtained. The relationship between the natural logarithm values of IPC and LEB is estimated with the cross-section data by the EViews 9 software (QMS, Emeryville, California, United States) (Table 6). The equation tells us that one year increase in natural logarithm value of LEB causes approximately $8.4 \%$ increase in natural logarithm value of IPC.

$\ln \left(\mathrm{IPC}_{2015}\right)=-27.44+8.41 \times \ln (\mathrm{LEB})_{2015} \ln$ : natural logarithm

In the equation, nearly $57.8 \%$ of the changes in IPC are expressed by LEB. The statistical values of the coefficients of the regression are statistically significant $(\mathrm{p}<0.05$ and the absolute values of the coefficients $t$ are outside the threshold values of the $t$ distribution). 
Table 5. Hausman test for random effects model to test the relationship between LEB and IPC (1990-2015)

\begin{tabular}{|c|c|c|c|c|}
\hline \multicolumn{5}{|c|}{$\begin{array}{l}\text { Correlated Random Effects - Hausman Test } \\
\text { Equation: Untitled } \\
\text { Test cross-section random effects }\end{array}$} \\
\hline \multicolumn{2}{|l|}{ Test Summary } & Chi-Sq. Statistic & Chi-Sq. d.f. & Prob. \\
\hline \multicolumn{2}{|l|}{ Cross-section random } & 15.308688 & 1 & 0.0001 \\
\hline \multicolumn{5}{|c|}{ Cross-section random effects test comparisons: } \\
\hline Variable & Fixed & Random & Var(Diff.) & Prob. \\
\hline LN_IPC & 0.048600 & 0.050412 & 0.000000 & 0.0001 \\
\hline \multicolumn{5}{|c|}{ Cross-section random effects test equation: } \\
\hline \multicolumn{5}{|c|}{ Dependent Variable: LN_LEB } \\
\hline \multicolumn{5}{|c|}{ Method: Panel Least Squares } \\
\hline \multicolumn{5}{|c|}{ Date: 05/01/17 Time: 19:07 } \\
\hline \multicolumn{5}{|l|}{ Sample: 19902015} \\
\hline \multicolumn{5}{|l|}{ Periods included: 26} \\
\hline \multicolumn{5}{|c|}{ Cross-sections included: 56} \\
\hline \multicolumn{5}{|c|}{ Total panel (balanced) observations: 1456} \\
\hline Variable & Coefficient & Std. Error & t-Statistic & Prob. \\
\hline C & 3.782082 & 0.015393 & 245.6976 & 0.0000 \\
\hline \multirow[t]{2}{*}{ LN_IPC } & 0.048600 & 0.002112 & 23.01327 & 0.0000 \\
\hline & Effects Specification & & & \\
\hline \multicolumn{5}{|c|}{ Cross-section fixed (dummy variables) } \\
\hline R-squared & 0.922065 & \multicolumn{2}{|c|}{ Mean dependent var } & 4.135306 \\
\hline Adjusted R-squared & 0.918946 & \multicolumn{2}{|c|}{ S.D. dependent var } & 0.156840 \\
\hline S.E. of regression & 0.044652 & \multicolumn{2}{|c|}{ Akaike info criterion } & -3.341459 \\
\hline Sum squared resid & 2.789369 & \multicolumn{2}{|c|}{ Schwarz criterion } & -3.134621 \\
\hline Log likelihood & 2489.582 & \multicolumn{2}{|c|}{ Hannan-Quinn criter. } & -3.264290 \\
\hline F-statistic & 295.5702 & \multicolumn{2}{|c|}{ Durbin-Watson stat } & 0.449021 \\
\hline Prob(F-statistic) & 0.000000 & & & \\
\hline
\end{tabular}

C - constant, EGLS - Estimated Generalized Least Squares, LN_IPC - natural logarithm of IPC, LN_LEB - natural logarithm of LEB, LEB - life expectancy at birth, IPC - economic growth, S.E. - standard error, S.D. - standard deviation, R-squared - statistical measure that represents the proportion of the variance for a dependent variable that's explained by an independent variable, F-statistic - the test statistic for testing the statistical significance of the model

\section{THE RELATIONSHIP BETWEEN IPC AND LEB WITH RANDOM EFFECTS MODEL (REM, 1990-2015)}

The following estimated equation tells the relationship between the natural logarithm values of IPC and LEB by REM regression with panel data. One unit increase in LEB causes an increase of nearly 5.78 units in IPC of the 56 developing countries.

$\ln (\text { IPC })_{1995-2015}=-16.64+5.78 \times \ln (\mathrm{LEB})_{1995-2015}$

The regression of the relationship between natural logarithm values of IPC and LEB values for the 56 developing countries obtained by the REM Panel Data covering the 26 years using the EViews 9 software can be seen as below (Table 7).

The regression above shows that about $29.5 \%$ of the changes in the IPC is expressed by the LEB values of the 56 developing countries. When the statistical values of the coefficients of the regression are examined; LEB (slope) and the constant coefficient are statistically significant $(P<0.05$ and the absolute values of the coefficients' $t$ are outside the threshold values of the $t$ distribution). Considering the relationship between the IPC and LEB values of the 56 develop- ing countries according to the regression results obtained in previous section by using the Cross-sectional Data Method is also confirmed by the regression results obtained using the Panel Data Method. If the regression is wanted to be obtained by Pooled Ordinary Least Squares Method it would be as; $\ln (\text { IPC })_{1995-2015}=-21.3+6.91 \times \ln (\text { LEB })_{1995-2015}$.

To test the validity of the REM, which shows the relationship between natural logarithm values of IPC and LEB obtained with the EViews 9 software above with the Hausman Test:

$\mathrm{H}_{0}$ : REM can be applied,

$\mathrm{H}_{1}$ : FEM can be applied.

The following Hausman test also shows that we cannot reject the null hypothesis indicating REM can be applied since with $1 \mathrm{df}$ (degree of freedom) and $X^{2}$ (chi-square) value is not statistically significant (Table 8).

If the null hypothesis is rejected, the alternative one which tells us FEM can be applied for the relationship should be accepted and the regression estimated by FEM should be as below.

$$
\ln (\text { IPC })_{1995-2015}=-16.098+5.65 \times \ln (\mathrm{LEB})_{1995-2015}
$$




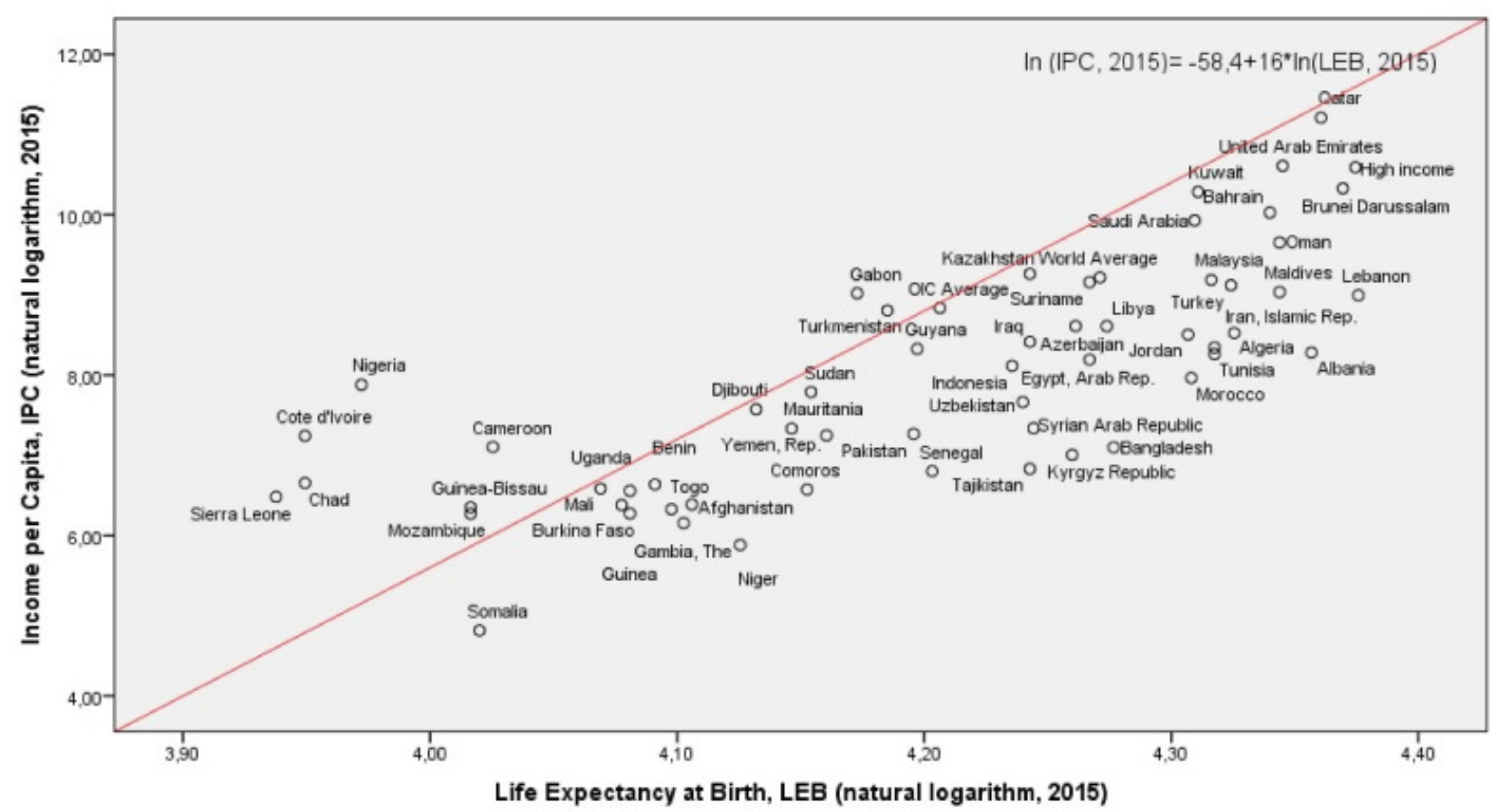

Figure 4. IPC and LEB relationship in 56 developing countries (2015). ${ }^{15-18}$

Table 6. The relationship between IPC and LEB with Cross-section Data Method (2015)

\begin{tabular}{|c|c|c|c|c|}
\hline \multicolumn{5}{|c|}{$\begin{array}{l}\text { Dependent Variable: LN_IPC } \\
\text { Method: Least Squares } \\
\text { Date: 05/01/17 Time: } 17: 58 \\
\text { Sample: } 156 \\
\text { Included observations: } 56\end{array}$} \\
\hline Variable & Coefficient & Std. Error & T-Statistic & Prob. \\
\hline C & -27.44122 & 4.112199 & -6.673126 & 0.0000 \\
\hline LN_LEB & 8.411891 & 0.978918 & 8.593050 & 0.0000 \\
\hline R-squared & 0.577599 & \multicolumn{2}{|c|}{ Mean dependent var } & 7.879959 \\
\hline Adjusted R-squared & 0.569776 & \multicolumn{2}{|c|}{ S.D. dependent var } & 1.373745 \\
\hline S.E. of regression & 0.901059 & \multicolumn{2}{|c|}{ Akaike info criterion } & 2.664569 \\
\hline Sum squared resid & 43.84301 & \multicolumn{2}{|c|}{ Schwarz criterion } & 2.736903 \\
\hline Log likelihood & -72.60794 & \multicolumn{2}{|c|}{ Hannan-Quinn criter. } & 2.692613 \\
\hline F-statistic & 73.84050 & \multicolumn{2}{|c|}{ Durbin-Watson stat } & 2.308470 \\
\hline Prob(F-statistic) & 0.000000 & & & \\
\hline
\end{tabular}

C - constant, EGLS - Estimated Generalized Least Squares, LN_IPC - natural logarithm of IPC, LN_LEB - natural logarithm of LEB, LEB - life expectancy at birth, IPC - economic growth, S.E. - standard error, S.D. - standard deviation, R-squared - statistical measure that represents the proportion of the variance for a dependent variable that's explained by an independent variable, F-statistic - the test statistic for testing the statistical significance of the model

The regression above shows that about $89.4 \%$ of the changes in the IPC is expressed by the LEB values of the 56 developing countries.

\section{GRANGER CAUSALITY TESTS}

The Granger Causality tests may be approved for both panel and cross-section data sets to show the direction of the causality between LEB and IPC and vice versa.

To test LEB causes IPC:

$\ln (\mathrm{IPC})_{\mathrm{it}}=\alpha_{\mathrm{I}}+\beta_{\mathrm{I}} \times \ln (\mathrm{LEB})_{\mathrm{it}}+\mathrm{U}_{\mathrm{it}}$
$\mathrm{H}_{0}$ : LEB does not Granger cause IPC

$\mathrm{H}_{1}$ : LEB Granger causes IPC

To test IPC causes LEB:

$\ln (\mathrm{LEB})_{\mathrm{it}}=\alpha_{\mathrm{I}}+\beta_{\mathrm{I}} \times \ln (\mathrm{IPC})_{\mathrm{it}}+\omega_{\mathrm{it}}$

$\mathrm{H}_{0}$ : IPC does not Granger cause LEB

$\mathrm{H}_{1}$ : IPC Granger causes LEB

$\mathrm{i}=1,2,3 \ldots 56, \mathrm{t}=1990-2015$ (26 periods) for panel data and $t=2015$ for cross-section data and the disturbances $\boldsymbol{v}_{\mathbf{i t}}$ and $\boldsymbol{\omega}_{\mathbf{i t}}$ are uncorrelated.

According to the Table 9 results computed $\mathrm{F}$ values exceed the critical $\mathrm{F}$ value and $P<0.05$ level of significance so 
Table 7. The relationship between IPC and LEB with REM

\begin{tabular}{|c|c|c|c|c|}
\hline \multicolumn{5}{|c|}{$\begin{array}{l}\text { Dependent Variable: LN_IPC } \\
\text { Method: Panel EGLS (Cross-section random effects) } \\
\text { Date: } 05 / 01 / 17 \text { Time: } 19: 03 \\
\text { Sample: } 19902015 \\
\text { Periods included: } 26 \\
\text { Cross-sections included: } 56 \\
\text { Total panel (balanced) observations: } 1456 \\
\text { Swamy and Arora estimator of component variances }\end{array}$} \\
\hline Variable & Coefficient & Std. Error & t-Statistic & Prob. \\
\hline C & -16.63877 & 0.973959 & -17.08364 & 0.0000 \\
\hline LN_LEB & 5.781120 & 0.233905 & 24.71570 & 0.0000 \\
\hline \multicolumn{5}{|c|}{ Effects Specification } \\
\hline & & & S.D. & Rho \\
\hline Cross-section random & & & 0.847646 & 0.7561 \\
\hline Idiosyncratic random & & & 0.481461 & 0.2439 \\
\hline \multicolumn{5}{|c|}{ Weighted Statistics } \\
\hline R-squared & 0.295542 & \multicolumn{2}{|c|}{ Mean dependent var } & 0.804625 \\
\hline Adjusted R-squared & 0.295057 & \multicolumn{2}{|c|}{ S.D. dependent var } & 0.573843 \\
\hline S.E. of regression & 0.481804 & \multicolumn{2}{|c|}{ Sum squared resid } & 337.5244 \\
\hline F-statistic & 609.9971 & \multirow{2}{*}{\multicolumn{2}{|c|}{ Durbin-Watson stat }} & 0.215498 \\
\hline Prob(F-statistic) & 0.000000 & & & \\
\hline \multicolumn{5}{|c|}{ Unweighted Statistics } \\
\hline R-squared & 0.543495 & \multicolumn{2}{|c|}{ Mean dependent var } & 7.267934 \\
\hline Sum squared resid & 1398.369 & \multicolumn{2}{|c|}{ Durbin-Watson stat } & 0.052015 \\
\hline
\end{tabular}

C - constant, EGLS - Estimated Generalized Least Squares, LN_IPC - natural logarithm of IPC, LN_LEB - natural logarithm of LEB, LEB - life expectancy at birth, IPC - economic growth, S.E. - standard error, S.D. - standard deviation, R-squared - statistical measure that represents the proportion of the variance for a dependent variable that's explained by an independent variable, F-statistic - the test statistic for testing the statistical significance

of the model

we reject both null hypotheses and accept that LEB Granger causes IPC and vice versa for panel data model.

According to the Table 10 results computed $F$ values do not exceed the critical $\mathrm{F}$ value and $P>0.05$ level of significance so we are not able to reject both null hypotheses which imply that LEB Granger does not cause IPC and vice versa for cross-section model.

\section{DISCUSSION}

Analysis of the results of Cross Section Model estimation shows that the equation $\ln (\text { LEB })_{2015}$ $=3.66+0.07 \times \ln (\text { IPC })_{2015} \ln$ : natural logarithm, tells us one percent increase in natural logarithm value of IPC causes approximately $7 \%$ increase in natural logarithm value of LEB which means nearly 8.108 USD increase in IPC for 56 developing countries in average causes 4.51 years increase in LEB in 56 OIC's average. In the equation about $57.8 \%$ of the changes in LEB are expressed by IPC.

When the relationship between natural logarithm value of LEB and natural logarithm value of IPC is wanted to be expressed by REM regression the equation is, ln $(\text { LEB })_{1995-2015}=3.77+0.05 \times \ln ($ IPC) $1995-2015$ is estimated. It means that nearly 8.108 USD increase in IPC for 56 developing countries in average causes nearly 3.27 years increase in LEB in average.
Since the Hausman test results indicate that FEM is appropriate rather than REM, the equation should be as, ln $(L E B)_{1995-2015}=3.782+0.0486 \times \ln ($ IPC) $1995-2015$.The regression of the relationship between natural logarithm values of LEB and IPC for the 56 developing countries obtained by the FEM panel data covering the 26 years obtained using the EViews 9 software (QMS, Emeryville, California, United States) shows that about $92.2 \%$ of the changes in the LEB of the 56 developing countries is expressed by IPC values of the countries. And the regression also means that nearly 8.108 USD increase in IPC for 56 developing countries in average causes nearly 3.16 years increases in LEB in average. Analysis of the results of Cross Section Model estimation shows that the equation $\ln (\text { IPC })_{2015}$

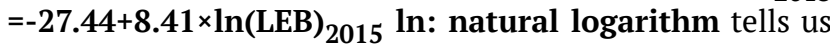
one percent increase in natural logarithm value of LEB causes approximately $8.4 \%$ increase in natural logarithm value of IPC. In the equation about $57.8 \%$ of the changes in IPC are expressed by LEB.

When the relationship between natural logarithm value of IPC and natural logarithm value of LEB was expressed by random effects model (REM) regression the equation ln (IPC) $_{1995-2015}=-16.64+5.78 \times \ln ($ LEB) $1995-2015$ is estimated. In the equation about $29.5 \%$ of the changes in IPC are expressed by LEB. The Hausman test results indicate that REM is appropriate rather than FEM.

The results reveal that LEB has significantly positive effect on IPC of a country hence economic growth. Also, an 
Table 8. Hausman test for random effects model to test the relationship between IPC and LEB

\begin{tabular}{|c|c|c|c|c|}
\hline \multicolumn{5}{|c|}{ Correlated Random Effects - Hausman Test } \\
\hline \multicolumn{5}{|l|}{ Equation: Untitled } \\
\hline \multicolumn{5}{|c|}{ Test cross-section random effects } \\
\hline Test Summary & & $\mathrm{x}^{2}$ Statistic & $x^{2}$ d.f. & Prob. \\
\hline Cross-section random & & 3.070898 & 1 & 0.0797 \\
\hline \multicolumn{5}{|c|}{ Cross-section random effects test comparisons: } \\
\hline Variable & Fixed & Random & $\operatorname{Var}$ (Diff.) & Prob. \\
\hline LN_LEB & 5.650324 & 5.781120 & 0.005571 & 0.0797 \\
\hline \multicolumn{5}{|c|}{ Cross-section random effects test equation: } \\
\hline \multicolumn{5}{|c|}{ Dependent Variable: LN_IPC } \\
\hline \multicolumn{5}{|c|}{ Method: Panel Least Squares } \\
\hline \multicolumn{5}{|c|}{ Date: 05/01/17 Time: 19:04 } \\
\hline \multicolumn{5}{|l|}{ Sample: 19902015} \\
\hline \multicolumn{5}{|l|}{ Periods included: 26} \\
\hline \multicolumn{5}{|c|}{ Cross-sections included: 56} \\
\hline \multicolumn{5}{|c|}{ Total panel (balanced) observations: 1456} \\
\hline Variable & Coefficient & Std. Error & t-Statistic & Prob. \\
\hline $\mathrm{C}$ & -16.09788 & 1.015398 & -15.85377 & 0.0000 \\
\hline LN_LEB & 5.650324 & 0.245525 & 23.01327 & 0.0000 \\
\hline \multicolumn{5}{|c|}{ Effects Specification } \\
\hline \multicolumn{5}{|c|}{ Cross-section fixed (dummy variables) } \\
\hline R-squared & 0.894132 & \multicolumn{2}{|c|}{ Mean dependent var } & 7.267934 \\
\hline Adjusted R-squared & 0.889894 & \multicolumn{2}{|c|}{ S.D. dependent var } & 1.450964 \\
\hline S.E. of regression & 0.481461 & \multicolumn{2}{|c|}{ Akaike info criterion } & 1.414379 \\
\hline Sum squared resid & 324.2951 & \multicolumn{2}{|c|}{ Schwarz criterion } & 1.621218 \\
\hline Log likelihood & -972.6683 & \multicolumn{2}{|c|}{ Hannan-Quinn criter. } & 1.491549 \\
\hline F-statistic & 210.9926 & \multicolumn{2}{|c|}{ Durbin-Watson stat } & 0.219181 \\
\hline Prob(F-statistic) & 0.000000 & & & \\
\hline
\end{tabular}

C - constant, EGLS - Estimated Generalized Least Squares, LN_IPC - natural logarithm of IPC, LN_LEB - natural logarithm of LEB, LEB - life expectancy at birth, IPC - economic growth, S.E. - standard error, S.D. - standard deviation, R-squared - statistical measure that represents the proportion of the variance for a dependent variable that's explained by an independent variable, F-statistic - the test statistic for testing the statistical significance of the model

Table 9. Pairwise Granger causality tests with panel data

\begin{tabular}{lccc}
\hline Pairwise Granger Causality Tests & & & \\
Date: 06/21/17 Time: $15: 35$ & & & \\
Sample: 19902015 & & & Obs \\
Lags: 2 & F-Statistic & Prob. \\
\hline Null Hypothesis: & 1344 & 5.81088 & 0.0031 \\
\hline LN_LEB does not Granger Cause LN_IPC & 4.57222 & 0.0105 & \\
LN_IPC does not Granger Cause LN_LEB &
\end{tabular}

LN_IPC - natural logarithm of IPC, LN_LEB - natural logarithm of LEB , LEB - life expectancy at birth, IPC - economic growth

increase in IPC enhances LEB. UNDP'S Human Development Index has also involved "The Life Expectancy Index" that is defined as a dimension of long and healthy life where LEB is an indicator of this sub-index. UN also puts the LEB in the centre of the human development with the gross national income. After testing the direction of causality between LEB and IPC of the countries in the study by the Granger causality test, it is seen that LEB Granger causes
IPC for panel data. For cross-section data analysis there is no proved correlation between LEB and IPC.

Azomahoo et al., ${ }^{4}$ Husain, ${ }^{10}$ Ecevit, ${ }^{11}$ Ngangue and Manfred $^{8}$ have found positive relationship between LEB and economic growth and Cervellati and Sunde ${ }^{12}$ have found positive relationship between LEB and economic growth after demographic transition analysing many countries together in their studies. Erdoğan and Bozkurt ${ }^{13}$, Akintunde 
Table 10. Pairwise Granger causality tests with cross-section data

Pairwise Granger Causality Tests
Date: $06 / 21 / 17$ Time: $15: 31$
Sample: 156
Lags: 2

LN_IPC - natural logarithm of IPC, LN_LEB - natural logarithm of LEB , LEB - life expectancy at birth, IPC - economic growth

et al. $^{6}$ and Mahyar $^{7}$, have found positive relationship between LEB and economic growth analysing a single country in their studies.

On the other hand, Acemoğlu and Johnson ${ }^{5}$ have found no relationship between LEB and economic growth analysing many countries together whereas Bowser ${ }^{9}$ has found no relationship between LEB and economic growth analysing a single country in their studies.

The improvements in healthcare system with the developments in innovation will decrease mortality rates in a country and promote to reach a long living population level with a higher LEB and healthy labour force enhancing productivity and economic growth in a country. This development occurs not at once but in time period as in the study our results show that economic growth Granger causes LEB increase only for panel data not for cross-section data. The data for LEB and IPC could not be retrieved easily. We used different international data sources to obtain the data for 56 developing countries analysed in the study.

C - constant, LN_IPC - natural logarithm of IPC; LN_LEB - natural logarithm of LEB, LEB - life expectancy at birth, IPC - economic growth, S.E. - standard error, S.D. - standard deviation, R-squared - statistical measure that represents the proportion of the variance for a dependent variable that's explained by an independent variable, F-statistic - the test statistic for testing the statistical significance of the model

C - constant, EGLS - Estimated Generalized Least Squares, LN_IPC - natural logarithm of IPC, LN_LEB - natural logarithm of LEB, LEB - life expectancy at birth, IPC economic growth, S.E. - standard error, S.D. - standard deviation, R-squared - statistical measure that represents the proportion of the variance for a dependent variable that's explained by an independent variable, F-statistic - the test statistic for testing the statistical significance of the model

C - constant, EGLS - Estimated Generalized Least Squares, LN_IPC - natural logarithm of IPC, LN_LEB - natural logarithm of LEB, LEB - life expectancy at birth, IPC economic growth, S.E. - standard error, S.D. - standard deviation, R-squared - statistical measure that represents the proportion of the variance for a dependent variable that's explained by an independent variable, F-statistic - the test statistic for testing the statistical significance of the model
C - constant, EGLS - Estimated Generalized Least Squares, LN_IPC - natural logarithm of IPC, LN_LEB - natural logarithm of LEB, LEB - life expectancy at birth, IPC economic growth, S.E. - standard error, S.D. - standard deviation, R-squared - statistical measure that represents the proportion of the variance for a dependent variable that's explained by an independent variable, F-statistic - the test statistic for testing the statistical significance of the model

C - constant, EGLS - Estimated Generalized Least Squares, LN_IPC - natural logarithm of IPC, LN_LEB - natural logarithm of LEB, LEB - life expectancy at birth, IPC economic growth, S.E. - standard error, S.D. - standard deviation, R-squared - statistical measure that represents the proportion of the variance for a dependent variable that's explained by an independent variable, F-statistic - the test statistic for testing the statistical significance of the model

C - constant, EGLS - Estimated Generalized Least Squares, LN_IPC - natural logarithm of IPC, LN_LEB - natural logarithm of LEB, LEB - life expectancy at birth, IPC economic growth, S.E. - standard error, S.D. - standard deviation, R-squared - statistical measure that represents the proportion of the variance for a dependent variable that's explained by an independent variable, F-statistic - the test statistic for testing the statistical significance of the model

LN_IPC - natural logarithm of IPC, LN_LEB - natural logarithm of LEB, LEB - life expectancy at birth, IPC - economic growth

LN_IPC - natural logarithm of IPC, LN_LEB - natural logarithm of LEB, LEB - life expectancy at birth, IPC - economic growth

\section{CORRESPONDENCE TO:}

Metin Gürler, MA, PhD

Uluslararası Rekabet Araştırmaları Kurumu (URAK)

Ünalan Mah. Ayazma Cad. Çamlıca İş Merkezi

A Blok Kat:3, 34700

Üsküdar/Istanbul

Turkey

meting@urak.org 


\section{REFERENCES}

1. United Nations Development Programme. The Human Development Indices an Indicators Report: 2018 Statistical Update. Accessed September 22, 2018. htt p://www.hdr.undp.org/sites/default/files/reports/294 7/2018 human development statistical update.pdf

2. United Nations Development Programme. Human Development Report: Human Development for Everyone. UNDP; 2016. Accessed October 12, 2018. http://ww w.hdr.undp.org/sites/default/files/2016_human_devel opment_report.pdf

3. United Nations Development Programme. Human Development Report: Work for Human Development. UNDP; 2015. Accessed October 15, 2018. http://hdr.u ndp.org/sites/default/files/2015_human_developmen t report 0.pdf

4. Azomahou TT, Boucekkine R, Diene B. A closer look at the relationship between life expectancy and economic growth. Int J Econ Theory. 2009;5(2):201-244. doi:10.1111/j.1742-7363.2009.001 05.X

5. Acemoğlu D, Johnson S. Disease and Development: The effect of life expectancy on economic growth. J Polit Econ. 2007;115(6):925-985. doi:10.1086/529000

6. Akintunde TS, Satope BF, Akanbi BE. The Impact of life expectancy on economic growth in Nigeria. The International Journal of Health Economics. 2016;6:44-56.

7. Mahyar H. Economic growth and life expectancy: The case of Iran. Studies in Business and Economics. 2016;11:80-87. doi:10.1515/sbe-2016-0007

8. Ngangue N, Manfred K. The impact of life expectancy on economic growth in developing countries. Asian Economic and Financial Review. 2015;5(4):653-660. doi:10.18488/journal.aefr/201 5.5.4/102.4.653.660
9. Bowser D. The Effect of Life Expectancy on Economic Growth in United States. Princeton University Papers; 2010.

10. Husain MI. Alternative estimates of the effect of the Increase of life expectancy on economic growth. Econ Bull. 2012;32(4):3025-3035.

11. Ecevit E. The impact of life expectancy on economic growth: panel cointegration and causality analyses for OECD countries. Int J Soc Sci (Islamabad). 2013;16:1.

12. Cervellati M, Sunde U. Life expectancy on economic growth: the role of the demographic transition. The Institute for the Study of Labor (IZA) Discussion Paper. 2009:4160.

13. Erdogan S, Bozkurt H. The relation between life expectation and economic growth in Turkey: an analysis with ARDL Model. Journal of Knowledge Economy \& Knowledge Management. 2008;3:25-38.

14. Gujarati DN, Porter DC. Basic Econometrics. 5th ed. McGraw-Hill/Irwin; 2009.

15. The World Bank Data Set. Accessed October 12, 2018. https://data.worldbank.org/

16. The Statistical, Economic and Social Research and Training Centre for Islamic Countries (Organisation of Islamic Countries Statistics-OICStat). Accessed October 12, 2018. http://www.sesric.org/oicstat.php

17. The IMF Data. Accessed October 12, 2018. http s://www.imf.org/en/data

18. United Nations Development Programme. Human Development data. Accessed May 10, 2017. http://hd r.undp.org/en/data 